\title{
The American Dream Revisited: A Corpus-Driven Study
}

\author{
Zhide $\mathrm{Hou}^{1}$ \\ ${ }^{1}$ Shenzhen Tourism College of Jinan University, Shenzhen, China \\ Correspondence: Zhide Hou, Shenzhen Tourism College of Jinan University, Shenzhen, Guangdong, China. \\ E-mail: zidhou@jnu.edu.cn
}

Received: February 3, 2017 Accepted: February 20, 2017 Online Published: March 1, 2017

doi:10.5539/ijel.v7n3p182

URL: http://doi.org/10.5539/ijel.v7n3p182

\begin{abstract}
As a dominant ideology throughout America, the American Dream rests on the idea that with hard work and personal determination anyone, regardless of background, has equal opportunity to achieve his or her aspirations. Given the importance of the American Dream to American national identity, and the enormity of it in shaping dominant ideologies, this study explores this deeply-held belief and particular mind-set in media discourses related to the American Dream. Modeled on the approach of corpus-driven discourse analysis, and combining the framework of a sociocultual linguistic approach to identity and interaction, the article reports on a corpus-driven sociocultural discourse study which aims to discover, through the analysis of frequent lexical and semantic patterns, discursive characteristics of media discourses related to the American dream, and whether there are any changes of the American dream to American national identity and ideologies which might be developed in time and space.
\end{abstract}

Keywords: the American Dream, media discourse, corpus-driven, identity, ideology

\section{Introduction}

The term American Dream was first used by the American historian James Truslow Adams in his book The Epic of America published in 1931. Later on, Martin Luther King Jr. spoke about a dream of freedom, equality, and justice, which then has become the widespread American way of life in general. As a great source of pride, the American Dream has become the central creed of American nation since 1931, which represents a basic belief in the power and capacity of the individual (Cullen, 2003; Schwarz, 1997). The seemingly egalitarian system of opportunity regardless of background each individual has equal chance to prosper resonates throughout contemporary American society. As Johnson (2006, p. 21) notes, the American dream is shared as the national ideology of meritocracy, a system "contingent upon a societal commitment to fair competition so that no individual or group is advantaged or disadvantaged by the positions or predicaments of their ancestors". But in fact, many individuals as well as scholars believe that the American Dream is not equally distributed among ethnic groups, which ultimately makes the dream an "inchoate fantasy" that has severe racial antagonisms embedded within it (Hochschild, 1995). In a same vein, Devos et al. (2010) examine the exclusionary definition of the American identity which is more readily granted to members of the dominant ethnic group, while other ethnic groups, at the minimum, are not created equal in their pursuit of the American dream and their aspirations to acquire the national identity. Findings show some individuals are relegated at the margin of the American identity because their group does not fit its prototypical definition, which contributed to a growing literature on the ramifications and consequences of defining a super ordinate identity in a way that excludes some subgroups.

While the specifics of each dream may vary from person to person, the overall vitality of the American Dream has been fundamental to American identity which is discursively produced, reproduced, transformed and destructed by means of language and other semiotic systems. Previous examinations on American identity have been focused on liberalism - America as a land of freedom and opportunity, and ethnoculturalism - America as a nation of white Protestants (Schildkraut, 2007). But identities as "a localized national culture" (Dervin, 2011), are always re/created in specific contexts and are usually fragmented, dynamic and changeable (Kellner, 1995; Park, 2007; Bucholtz \& Hall, 2005; Wodak, 2011). American identity and the media discourses related to the American Dream have a dialectic relationship, because the media discourses manifest "who they are" and define reality partly through language use in the media.

Corpus investigations of media discourses related to the American Dream contributing to American national 
identity and ideologies have been lacking. An important motivation of investigating the media representations of the American Dream is that it already existed in electronic form, although care needs to be taken when assuming that a person who has posted a message actually possesses the identity they claim to have. The corpus-driven quantitative research actually does help to uncover the secret of the American Dream in modern society.

\section{Framework and Methodology}

Discourse and identity are closely connected. Identity is always defined via similarity and difference (e.g., Ricoeur, 1992; Wodak et al., 2009). In the process of identity formation, news media plays a crucial role not only mirror some kind of objective reality, but also acts as powerful social agent in its own right. Through media reports, journalists as social actors can constitute objects of knowledge, situations as well as identities between different social groups and readers. Following Wodak et al. (1999, p. 22), identity is "constructed and conveyed in discourse, predominantly in narratives of national culture". The present study adopts Bucholtz \& Hall's (2005) sociocultural linguistic perspective on identity. Identity produced in linguistic interaction based on the following principles: identity is best viewed as the emergent product rather than the pre-existing source of linguistic and other semiotic practice; identity relations emerge in interaction through several related indexical processes, such as the use of linguistic structures and systems that are ideologically associated with specific persons and groups; identities are never autonomous or independent but always acquire social meaning in relation to other available identity positions and other social actors (Bucholtz \& Hall, 2005, pp. 585-614).

The American media discourses related to the American Dream, with data collected from January 2012 to December 2016 are examined in this study. One important consideration of choosing data during this time span is America under the former American President Obama's administration since his second term of presidency in 2012. The research questions are: What are the discursive characteristics of media discourse related to the American dream? Did the media discourses related to the American Dream reflect the American identity and dominant ideologies? If not, how has the American Dream to American identity and ideologies changed over time? To address the questions, the American Dream Corpus (ADC) of media texts with 99,832 words in 112 news articles are retrieved from the Newspaper database EBSCO host. All the articles are constrained to the American media because they represent the American ideologically construed social and political positions to international readers. Prominent newspapers with higher circulation include Washington post, The New York Times, Wall Street Journal, USA Today Tribune, and Christian Science Monitor, with detailed descriptions in Table 1. The criterion for selecting articles is that American Dream has to be the primary topic and appear in the title. This is done with a view to including only articles in which the American Dream is discussed as the major topic and to exclude texts in which the two words American Dream are mentioned only in passing.

Table 1. Data description of American Dream Corpus

\begin{tabular}{lll}
\hline & Texts $(\boldsymbol{n})$ & Words $(\boldsymbol{n})$ \\
\hline American Dream media corpus & & \\
Washington Post & 37 & 31,393 \\
The New York Times & 21 & 24,847 \\
Wall Street Journal & 19 & 18,566 \\
USA Today & 15 & 11,908 \\
Tribune & 12 & 7,709 \\
Christian Science Monitor & 8 & 5,409 \\
\hline Total & 112 & $\mathbf{9 9 , 8 3 2}$ \\
\hline
\end{tabular}

ConcGram 1.0 (Greaves, 2009) and Wmatrix (Rayson, 2001) are used as tools to retrieve two/three-word concgrams, keywords and key semantic categories and relevant concordances, from which analyses will be conducted below.

\section{Discussion of Findings}

\subsection{Two-word Concgrams}

As the identification of keywords can indicate what a corpus is about, the "aboutness" of a text or homogeneous corpus (Scott, 1999), the two-word concgrams in the study corpus offers "a first glimpse of the dominant theme and topic throughout the texts" (Cheng \& Lam, 2013, p. 180). The top ten two-word concgrams in Table 2, with the exclusion of function/grammatical words, tells the dominant theme on the American Dream. The most frequent two-word concgram American/dream and the quotation-related concgram (said/who) and people-related 
concgrams (class/middle, more/people and high/school) are prominent, indicating the individualistic value of the American Dream, probably the American middle class are more concerned about their American Dream.

Table 2. The top 10 most frequently occurring two-word concgrams of ADC

\begin{tabular}{lll}
\hline Rank & Two-word concgrams & Frequency \\
\hline 1 & American/dream & 171 \\
2 & more/than & 110 \\
3 & States/United & 59 \\
4 & don/don't & 51 \\
5 & said/who & 45 \\
6 & less/than & 31 \\
7 & class/middle & 28 \\
8 & last/year & 27 \\
9 & more/people & 26 \\
10 & high/school & 26 \\
\hline
\end{tabular}

\subsection{Keywords and Key Semantic Categories}

Keywords act as a standard reference for normal frequencies of words that reveal something of the "aboutness" of a particular corpus. For the purpose of this analysis, ADC is compared against the AmE06, a very good reference corpus as it matched reasonably the data in terms of national and international variety of English. The top 20 keywords, relative to AmE06, listed in Table 3, confirmed the dominant theme and topic of the American Dream in the ADC, which further support the two initial observations from the two-word concgram analysis. The keywords also showed the preoccupation of individualistic issues related to the Americans and their "homes", "housing", "mortgage" and "family". Another noticeable keyword is "China", implying the American Dream is not independent from China.

Table 3. The top 20 keywords of ADC when compared with AmE06

\begin{tabular}{llll}
\hline Rank & Keywords vs AmE06 & Rank & Keywords vs AmE06 \\
\hline 1 & dream & 11 & buyers \\
2 & American & 12 & U.S. \\
3 & home & 13 & economic \\
4 & Americans & 14 & says \\
5 & homes & 15 & loan \\
6 & mortgage & 16 & homeowners \\
7 & housing & 17 & China \\
8 & said & 18 & -- \\
9 & people & 19 & income \\
10 & family & 20 & triple \\
\hline
\end{tabular}

With the help of Wmatrix, researchers are able to see "to what extent particular grammatical phenomena, as well as particular semantic domains, feature in a corpus" (O'Halloran, 2010, p. 178). The semantic domains or categories of ADC, relative to AmE06, offered the key semantic categories and their respective keywords which should be unique to American identity and ideology (Table 4). Consistently, the keywords in the categories showed the same as what the Americans related to or interested in are "home", "China", "mortgage" and etc.

Table 4. Semantic categories and keywords in the ADC when compared with AmE06

\begin{tabular}{ll}
\hline Key semantic categories & Keywords \\
\hline Residence & Home (172), homes (63), living (37), live (31), residents (13) \\
Geographical names & American (246), Americans (102), America (62), United States (58), China (39), Washington \\
& $(31)$, Chinese (31) \\
Money and pay & Income (36), tax (35), afford (26), taxes (25) \\
Money: debts & Mortgage (49), pay (29), debt (25), loan (21) \\
Business: selling & Buyers (31), bought (21), rentals (21), rent (21) \\
\hline
\end{tabular}


The above key semantic categories and keywords (Table 4), combining with the most frequent two-word concgrams (Table 1), guided the user to the analysis of the American Dream itself, American middle class, home and its relation with China.

\subsection{The American Dream as an Emergent Product}

Knowing the most frequently occurring two-word concgram American/dream, the discursive construction of the American Dream can be best analyzed from the concordance lines of the three-word concgram American/dream/is and American/dream/of, because the co-dependence of lexis and grammar from one another exert "a major impact on the way in which we describe language in use" (Adolphs, 2006, p. 51). Likewise, Sinclair (1991) also notes, the preposition of often occurs with nouns to form nominal groups, in which the first element can often denote a measure or an attribute. In order to see what attributes are frequently associated with the American Dream, the most frequent collocates appearing to the right side of the pattern American/dream/is are examined.

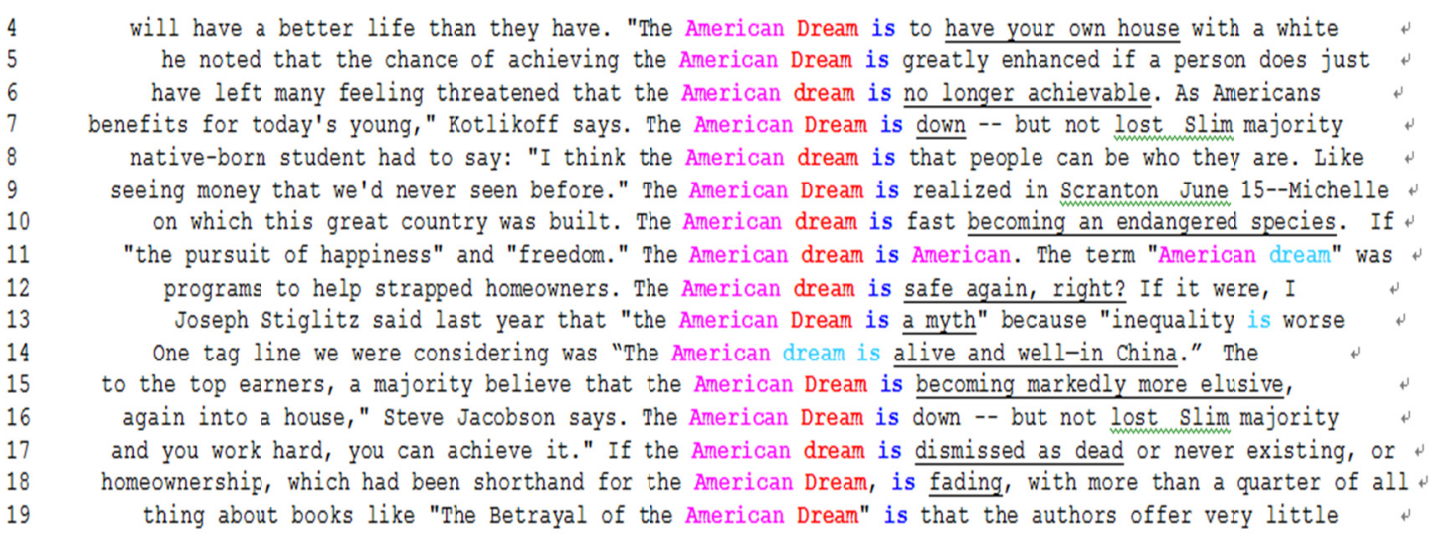

Figure 1. Concordances of three-word concgram American/dream/is

The above pattern of concordance lines (figure 1) strongly indicates a tendency of evoking negative representations of the American Dream. The American Dream is discursively defined as no longer achievable, down, becoming an endangered species, becoming markedly more elusive, dismissed as dead, fading, signifying each individual's American Dream as an emergent contribution to his identity in case when speaker's language use does not conform to the category of the American Dream to which it is normatively assigned with equal opportunity to achieve his or her aspirations.

Another useful pattern to discover the discursive characteristics of the American Dream is to examine the concordance lines of American/dream/of (figure 2). Some of these media representations of the American Dream tend to portray the epitome, definition, condition and concept of itself, while others implied the violation, betrayal and even death of the American Dream. In addition, house, homeownership and college became important factors in realizing the American Dream. The American "middle class gets priced out of American dream", as one concordance lines reads, implied the challenge of the American middle class's pursuit of the American Dream - their aspirations to acquire the national identity. 


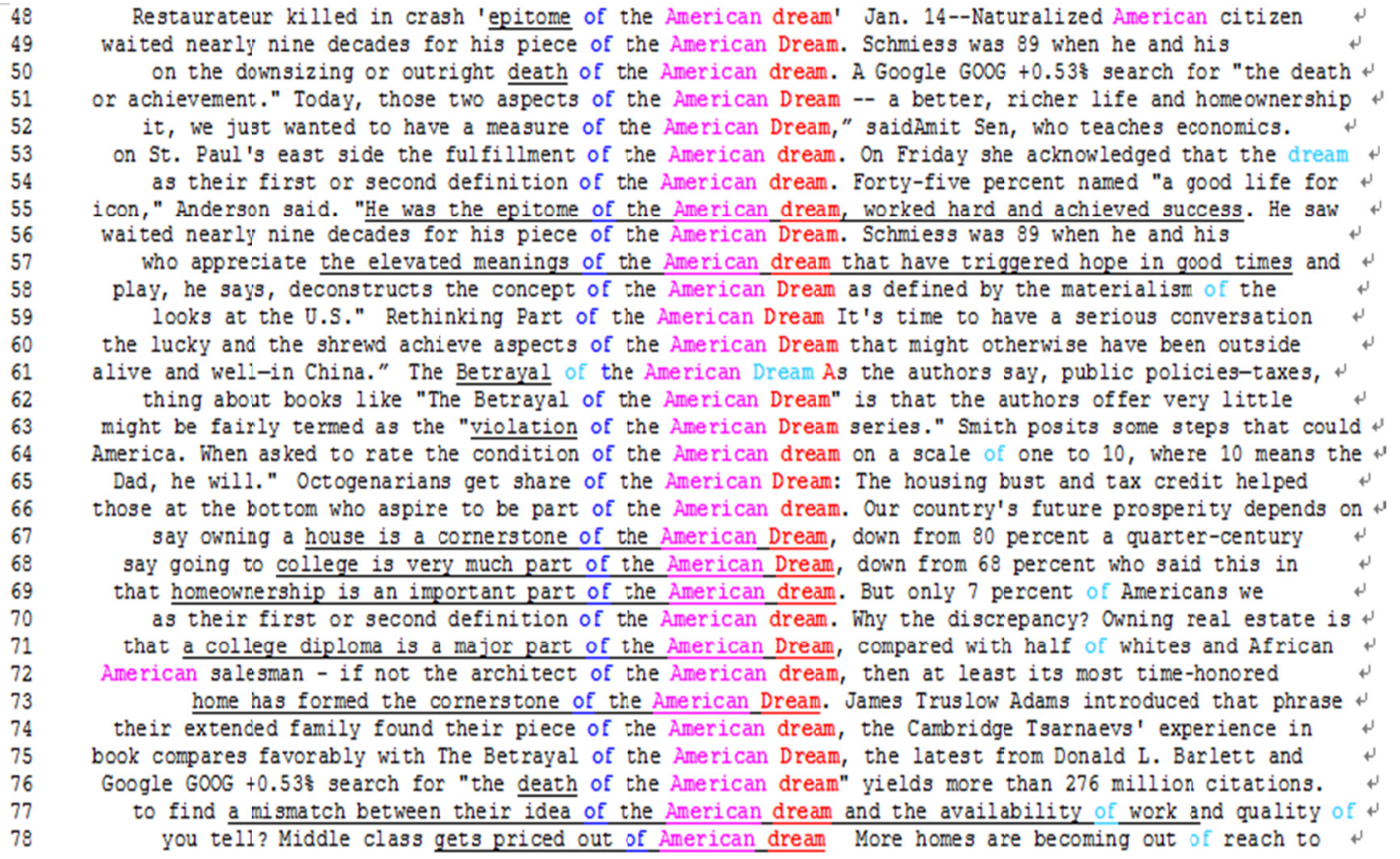

Figure 2. Concordances of three-word concgram American/dream/of

\subsection{The Dream of American Middle Class}

According to Gilbert (1998), the American middle class are persons commonly have a comfortable standard of living, significant economic security, considerable work autonomy and rely on their expertise to sustain themselves. The American middle class identity is used to be known around the world for conspicuous consumption. To this day, the professional middle class in the United States holds the world record for having the largest homes, most appliances, and most automobiles. In a same vein, Archer \& Blau (1993) note that the American middle class owes much of its historical identity to the occupational stability provided by the jobs that its representatives filled and to its geographic sedentariness. But what are the media representations of middle class in modern America? As middle/class is one the top two-word concgrams (see table 1), and "home" one of the top keywords (see table 2), the examination of the pattern middle/class and its collocation with home or house will provide ideologically associated linguistic structures of American middle class and their homeownership in the realization of the American Dream.

8 homes are becoming out of reach to buyers Middle-class home buyers are finding fewer homes on the market
9 homes this month were out of reach for middle-class buyers, data from real estate tracker Trulia
10 are combining to limit choices for the middle class, says Jed Kolko, Trulia chief economist. Trulia
11 Trulia considers homes affordable for middle-class buyers if their total monthly payment -- after a
12 The drop-off in affordable homes for middle-class buyers is widespread, falling or flattening in 99
13 orange County, Calif. were affordable for middle-class buyers, Trulia's data show. That's down from $44 \%$
14
drops in housing affordability for middle-class buyers have been in California. Significant
16 also are occurring elsewhere. Boston's middle-class buyers can afford $41 \%$ of the homes on the market
17 of the homes were still within reach of middle-class buyers, Trulia's data show. Middle-class buyers
18 offering effective solutions to help the middle class. Democrats are more likely than Republicans to
19 median size of an affordable home for a middle-class buyer in the New York metro region was 978 square
20 thus far has been the 300 million-strong middle class. That's less than a third of the population.

Figure 3. Concordances of two-word concgram middle/class

Clearly, more concordance lines above implied negative media representations of American middle class when they are home buyers. This result might help to explain the stereotypical representation of the largest homes of American middle class as American identity contradicts what is real in media representations. What is more 
interesting is "the home was the only way to join the middle class" as one concordance line tells, indicating the strong desire of homeownership for American middle class because home promotes social stability. This result echoes with what Kroos (2012, p. 320) notes that "the American Dream in the contemporary equivalents of motor cars and high wages gets translated into homeownership".

\subsection{The American Dream not Independent from China}

There is little wonder that the American Dream gained immense market share and is still widely equated with the general aspiration of obtaining a high living standard and human dignity. China, America's most important partner either in economy or politics, has become America's strong competitor in the $21^{\text {st }}$ century. The American Dream is never independent from other social actors, especially when the recently announced Chinese Dream meaning the great rejuvenation of the Chinese nation has become the "twin" of the American Dream. In the following, the three-word concgram American/dream/China (figure 4) is searched for concordance analysis so as to examine their relationship in media representations.

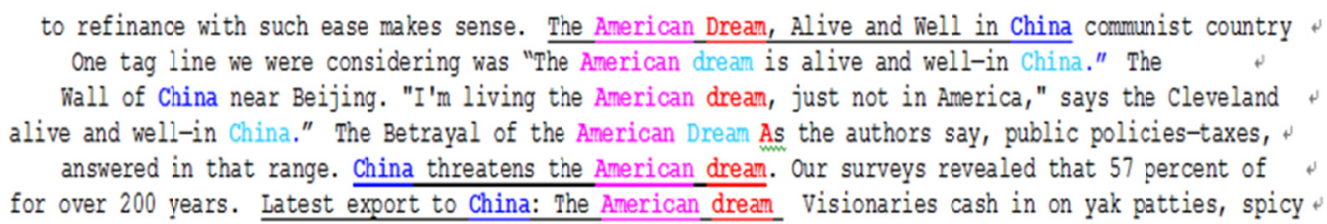

Figure 4. Concordances of three-word concgram American/dream/China

An expanded examination of the above three underlined concordance lines tells the fact that they are titles of three news articles from The Wall Street Journal, Washington Post and USA today respectively, indicating the American identity to which the American Dream ascribes is never autonomous or independent but acquire social meaning in relation to the strong impact of the uprising China.

\section{Conclusion}

By conducting a corpus-driven sociocultural discourse study (Bucholtz \& Hall, 2005) of the American Dream from the corpus of American media discourses, this study has demonstrated how the two areas of linguistic enquiry can be effectively and fruitfully combined, and the great potential of using ConcGram and Wmatrix. Through analyzing the most frequently occurring two-word concgrams, and keywords and key semantic categories contrasted against AmE06, and especially the concordance outputs, this study has shown the identity and ideology to which the American Dream contributed has undergone changes. The unachievable, elusive and even dead of American Dream are discursively constructed as central ideas to the American identity. The seemingly wealthy American middle class is getting priced out of the American Dream because of homeownership difficulty, implying the conflicts and negotiations of American middle class identity as well as the changing aspirations of the American Dream. The relational aspect of the American Dream to China indicated American identity emerged in relation to other identities such as the "threat" from China (one newspaper article entitled China threatens American Dream). These findings give insights into a new understanding of the American Dream in the $21^{\text {st }}$ century which is different from or even contradicts with what dominant American identities and ideologies central to American Dream in the $20^{\text {th }}$ century.

\section{References}

Adams, J. T. (1931). The epic of America. New York, NY: Atlantic Monthly Press.

Adolphs, S. (2006). Introducing electronic text analysis: a practical guide for language and literary studies. New York: Routledge.

Archer, M., \& Blau, J. R. (1993). Class formation in nineteenth-century America: The case of the middleclass. Annual Review of Sociology, 19, 17-41. http://dx.doi.org/10.1146/annurev.so.19.080193.000313

Bucholtz, M., \& Hall, K. (2005). Identity and interaction: a sociocultural linguistic approach. Discourse Studies, 7(4-5), 585-614. http://dx.doi.org/10.1177/1461445605054407

Cheng, W., \& Lam, P. W. Y. (2013). Western perceptions of Hong Kong ten years on: a corpus-driven critical discourse study. Applied Linguistics, 34(2), 173-190. http://dx.doi.org/10.1093/applin/ams038

Cullen, J. (2003). The American dream: a short history of an idea that shaped a nation. New York: Oxford 
University Press.

Dervin, F. (2011). Cultural identity, representation and othering. In J. Jackson (Ed.), Routledge handbook of intercultural communication (pp. 181-194). Abingdon: Routledge. http://dx.doi.org/10.4324/9780203805640.ch11

Devos, T., Gavin, K., \& Quintana, F. J. (2010). Say "adios" to the American dream? The interplay between ethnic and national identity among Latino and Caucasian Americans. Cultural Diversity \& Ethnic Minority Psychology, 16(1), 37-49. http://dx.doi.org/10.1037/a0015868

Gilbert, D. (1998). The American Class Structure. New York: Wadsworth Publishing.

Greaves, C. (2009). ConcGram 1.0: A Phraseological Search Engine. Amsterdam: John Benjamins. http://dx.doi.org/10.1075/z.159.17ind

Hochschild, J. L. (1995). Facing up to the American dream: Race, class, and the soul of the nation. Princeton, NJ: Princeton University Press.

Johnson, H. B. (2006). The American dream and the power of wealth. New York: Routledge.

Kroos, K. (2012). Becoming conscious of the American middle class (un)consciousness. Integrative Psychological \& Behavioral Science, 46(3), 312-34. http://dx.doi.org/10.1007/s12124-012-9206-y

O'Halloran, K. (2010). Investigating Argumentation in Reading Groups: Combining Manual Qualitative Coding and Automated Corpus Analysis Tools. Applied Linguistics, 32(2), 172-196. http://dx.doi.org/10.1093/applin/amq041

Park, J. E. (2007). Co-construction of Nonnative Speaker Identity in Cross-cultural Interaction. Applied Linguistics, 28(3), 339-360. http://dx.doi.org/10.1093/applin/amm001

Rayson, P. (2001). Wmatrix: A web-based corpus processing environment. Computing Department, Lancaster University.

Schildkraut, D. J. (2007). Defining American Identity in the Twenty-First Century: How Much "There" is There? The Journal of Politics, 69(3), 597-615. http://dx.doi.org/10.1111/j.1468-2508.2007.00562.x

Schwarz, J. E. (1997). Illusions of opportunity: the American dream in question. New York: W.W. Norton.

Scott, M. (1999). Wordsmith tools help manual, version 3.0. Oxford: Oxford University Press.

Sinclair, J. McH. (1991). Corpus, concordance, collocation. Oxford: Oxford University Press.

Wodak, R. (2011). Language, power and identity. Language Teaching, 45(2), 215-233. http://dx.doi.org/10.1017/S0261444811000048

\section{Copyrights}

Copyright for this article is retained by the author(s), with first publication rights granted to the journal.

This is an open-access article distributed under the terms and conditions of the Creative Commons Attribution license (http://creativecommons.org/licenses/by/4.0/). 